\title{
Taxonomic and ecological studies on the earthworms (Annelida: Oligochaeta) of West Khasi Hills District, Meghalaya
}

\author{
Ilona J. Kharkongor* \\ North Eastern Regional Centre, Risa Colony, Shillong - 793003, Meghalaya, India; \\ ilona.kharkongor@ymail.com
}

\begin{abstract}
The earthworms collected from the West Khasi Hills District of Meghalaya are dealt with in this paper. Besides the taxonomic identification of the earthworms in to 32 species fewer than 12 genera, 4 families and 2 orders, the species have also been assigned in to separate ecological groups. 6 species are epigeic or epi-anecic, 11 species are endogeic, 2 species are endoanecic, 5 species are endo-polyhumic and 1 species is endo-mesohumic. The list also includes 6 endemic species. Amynthas populosus is recorded for the first time from India, while 8 species are reported for the first time from Meghalaya. Out of the 32 species from the District, 31 species are recorded for the first time from West Khasi Hills district.
\end{abstract}

Keywords: Amynthas Populosus, Ecological Groups, Endemic Earthworms, Faunal List, First Record

\section{Introduction}

Studies on earthworms in the Indian Sub-continent began in 1844 when Templeton described a new species of earthworm from Sri Lanka. Since then a good number of scientists worked on the taxonomy of earthworm in India series of papers relating to the taxonomy of earthworms from India have been published by many workers, notably Beddard (1883), Rosa (1888, 1890), Bourne (1889), Michaelsen (1897, 1900, 1907, 1909), Fedarb (1898), Stephenson (1914, 1916, 1922, 1923), Gates (1945, 1951, 1972) and Julka (1976, 1978, 1981, 1988), which helped to enrich our knowledge on this group of organism. Out of the 13 earthworm families reported from India (Julka, 1995), only 5 families are known to occur in Meghalaya (Halder, 1999).

Review of literature published so far on the taxonomy of earthworm of Meghalaya shows that 34 species under 11 genera and 5 families are found in the State. Out of these 31 species only one species, Amynthas diffringens (Baird) is reported from West Khasi Hills District (WKHD) of the State (Halder, 1999). There is a clear indication that this entire area have been left out of the purview of studies by researchers working in the field of earthworm taxonomy. This lacuna has created an information gap that need to be filled up in order to get a clear and a more or less complete picture of the diversity of earthworm fauna of the state of Meghalaya. The present study has been undertaken with this objective in mind. Considering the fact that the West Khasi Hills District is the largest district in the State, with a vast area still undeveloped and inaccessible, it is expected that the area would harbour rich earthworm diversity.

\section{Study Area}

The WKHD of Meghalaya lying between co-ordinates $25^{\circ} 10^{\prime} \mathrm{N}$ to $25^{\circ} 51^{\prime} \mathrm{N}$ and $90^{\circ} 44^{\prime} \mathrm{E}$ to $91^{\circ} 49^{\prime} \mathrm{E}$, is one of the largest districts in the State. The area is hilly with large tracts of pine forests and mixed tropical, broad-leaved forests. Remote, inaccessible parts of the district are still covered with thick virgin forests. Numerous big and small rivers and streams criss-cross the difficult terrain. Vast areas of the land is also dominated by undulating hills

\footnotetext{
* Author for correspondence
} 
covered with only grass and sparse shrubs and dotted with huge boulders and stones, the low lying areas and valleys of which forms fertile fields for growing paddy and other agricultural crops, and also used for fisheries. Such a diversified area supports diverse ecosystems harbouring an equally diverse biodiversity. On the whole, it can be inferred that the District still harbours a rich diversity of flora and fauna and, probably, houses many new or yet-tobe-described species as the area is still sparsely populated, undeveloped and inaccessible. However, unchecked timber logging and unscientific charcoal making has led to large scale deforestation in many places. Unscientific rat-hole coal mining activity is also taking a toll on the otherwise pristine environments of the district. Added to this is the rampant sand quarrying along the riverbeds of the major rivers in the district which has resulted in highly turbid, polluted waters posing threats to the aquatic fauna and to fishery practices. Large scale stone quarrying is also rampant, and in some places an entire hill is lost to this activity. This not only changes the topography of the area but also contributes to forest loss, soil erosion, landslides, siltation of the already threatened riverbeds and loss of fertile agricultural lands. On the downside, all these activities are contributing factors to biodiversity loss due to habitat destruction.

\section{Material and Methods}

This report is based on a collection of earthworms made by a survey party of the North Eastern Regional Centre of the Zoological Survey of India, Shillong. The specimens were collected during June-July from various parts of the West Khasi Hills District of Meghalaya. Adequate measures were taken at the time of earthworm collection from diverse habitats including open grasslands, forested areas (both pine forests and broad-leaved forests), agricultural fields, degraded soils, humus rich soils, under manure heaps, stones, logs and decaying vegetable matters, etc. The specimens were collected by digging up the soil using spades, utmost care being taken not to damage them. The earthworms are then picked up by hand and narcotized in $70 \%$ alcohol. Once immobilized, the earthworms are then laid straight on blotting paper along with field labels and fixed in 10\% formalin. On return to the laboratory, the fixed earthworms are washed in freshwater and transferred to suitable-sized bottles filled with $70 \%$ alcohol as preservative, along with proper labels. The entire collection is registered in North Eastern Regional Centre, Zoological Survey of India, Shillong.

\section{Abbreviations and Symbols Used}

EKHD

WKHD

RBD

WGHD

JHD

IV/ANN/NERC
East Khasi Hills District

West Khasi Hills District

Ri Bhoi District

West Garo Hills District

Jaiñtia Hills District

Invertebrate/Annelida/North

Eastern Regional Centre

\section{Systematic List}

$\begin{array}{ll}\text { Phylum } & \text { ANNELIDA } \\ \text { Class } & \text { OLIGOCHAETA } \\ \text { Order } & \text { HAPLOTAXIDA } \\ \text { Family } & \text { MEGASCOLECIDAE }\end{array}$

Genus Amynthas Kinberg, 1867

1. Amynthas corticis (Kinberg)

2. Amynthas gracilis (Kinberg)

3. Amynthas papulosus (Rosa)

4. Amynthas robustus (Perrier)

Genus Polypheretima Michaelsen, 1934

5. Polypheretima elongata (Perrier)

Genus Megascolex Templeton, 1844

6. Megascolex horai Stephenson

7. Megascolex sp.

Genus Notoscolex Fletcher, 1887

8. Notoscolex striatus Stephenson

9. Notoscolex sp.

Genus Nelloscolex Gates, 1939

10. Nelloscolex burkilli (Michaesen)

Genus Metaphire Sims and Easton, 1972

11. Metaphire houletti (Perrier)

12. Metaphire houletti morph (Gates)

13. Metaphire birmanica (Rosa)

14. Metaphire posthuma (Vaillant)

Genus Perionyx Perrier, 1872

15. Perionyx foveatus Stephenson

16. Perionyx fossus Stephenson 
17. Perionyx horai Stephenson

18. Perionyx excavatus Perrier

Genus Kanchuria Julka, 1988

19. Kanchuria octotheca Julka

20. Kanchuria sumerianus Julka

21. Kanchuria turaensis Julka

Family LUMBRICIDAE

Genus Aporrectodea Orley, 1885

22. Aporrectodea trapezoides (Dugès)

Family OCTOCHAETIDAE

Genus Dichogaster Beddard, 1888

23. Dichogaster bolaui (Michaelsen)

24. Dichogaster saliens (Beddard)

Genus Eutyphoeus Michaelsen, 1900

25. Eutyphoeus festivus Gates

26. Eutyphoeus callosus Gates

Order MONILIGASTRIDA

Family MONILIGASTRIDAE

Genus Drawida Michaelsen, 1900

27. Drawida nepalensis Michaelsen

28. Drawida pellucida f. stewarti Stephenson

29. Drawida pellucida f. typica (Bourne)

30. Drawida rosea Stephenson

31. Drawida sp. 1

32. Drawida sp. 2

\section{Systematic Account}

\section{Class OLIGOCHAETA}

Order HAPLOTAXIDA

Family I MEGASCOLECIDAE

Genus 1: Amynthas Kinberg, 1867

\section{Amynthas corticis (Kinberg, 1867)}

1867. Perichaeta corticis Kinberg, Öfv. Kong. Vet-Akad. Förh. Stockholm, 23: 102.

1972. Amynthas diffringens: Sims \& Easton, Biol. J. Linn. Soc., 4(3): 235.

1981. Amynthas corticis, Easton, Bull. Br. Mus. Nat. Hist.(Zool.), 40(2): 49.

1995. Amynthas corticis, Julka, Fauna of West Himalaya, 1: 18.
Material examined: 1 ex. Regn. No. IV/ANN/NERC-02. India, Meghalaya, West Khasi Hills District, NongkhnumLailad, N2526'21.8": E91 '16’01.4"; Alt. 1377m,24.vi.2010, coll. I.J.Kharkongor and party; 6 ex. Regn. No. IV/ANN/ NERC-12. India, Meghalaya, West Khasi Hills District, Pamphyrnai, N 2532'19.5”; E 91²0'57.0”; Alt. 1556m, 26.vi.2010, coll. I.J.Kharkongor and party; 4 ex. Regn. No. IV/ANN/NERC-19. India, Meghalaya, West Khasi Hills District, Nongstoiñ-Nongpyndeng, N 2530'38.1"; E 9114'25.5”; Alt. 1382m, 26.vi.2010, coll. I.J.Kharkongor and party; 1 ex. Regn. No. IV/ANN/NERC-20. India, Meghalaya, West Khasi Hills District, Mawthar village, near Puiñsneiñ stream, N 2528'05.0"; E 91'15'39.0”; Alt. $1407 \mathrm{~m}, 24 . v i .2010$, coll. I.J.Kharkongor and party; 4 ex. Regn. No. IV/ANN/NERC-32. India, Meghalaya, West Khasi Hills District, near Langja village, N 2542'27.9”; E 91'10'45.0"; Alt. 1062 m, 23.vi.2010, coll. I.J.Kharkongor and party; 1 ex. Regn. No. IV/ANN/NERC-34. India, Meghalaya, West Khasi Hills District, Mawshynrut village,

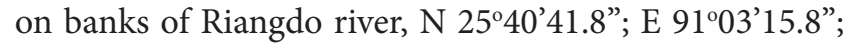
Alt. 913m, 22.vi.2010, coll. I.J.Kharkongor and party; 1 ex. Regn. No. IV/ANN/NERC-44. India, Meghalaya, West Khasi Hills District, Nongstoiñ - Mawlongphlang, N 2530'32.4"; E 91²14'23.5”; Alt. 1379m, 26.vi.2010, coll. I.J.Kharkongor and party.

Diagnosis: Length 40-166 mm; segments 70-118. Epilobic, tongue open. Perichaetine. First dorsal pore in 11/12 or 12/13. Clitellum annular, 14-16, setae absent. Dorsal pore absent. Spermathecal pores four pairs in 5/6-8/9. Genital papillae small, circular to somewhat elliptical discs, paired, presetal and/or post-setal in some or all of 6-9, always near spermathecal pores, in line with spermathecal pores or just median to line of pores. Female pore single in 14. Male pores paired in 18, on depressed corny pads.

Septa 5/6-7/8, 10/11-13/14 thickened, 8/9/10 absent. Gizzard in 8-10. Intestine from 15; intestinal caeca in 27, paired and simple. Spermathecae four pairs in 6-9; ovaries in 13 , and testis sacs a pair each in 10 and 11; seminal vesicles paired in 11 and 12 .

Distribution: INDIA : Meghalaya (JHD, EKHD, WGHD), Arunachal Pradesh, Assam, Himachal Pradesh, Jammu and Kashmir, Karnataka, Manipur, Sikkim, Tamil Nadu, Uttar Pradesh and West Bengal. Elsewhere: Cosmopolitan. 
Remarks: It is, herein, recorded for the first time from WKH District. This is the most widely distributed species of the pheretimoid earthworms. It has been recorded in many countries in East and Southeast, Australia, Europe, South America and South Africa. It has been classified as an epigeic and endogeic species of earthworm. It is found living and feeding in the mineral soil at or below the root mat, and also on the surface where there is a rich layer of litter, preferably leaf litter in moist undergrowth.

\section{Amynthas gracilis (Kinberg, 1867)}

1867. Nitocris gracilis Kinberg, Ofvers. K. Vetensk. Acad. Forth. Stockh., 23: 112.

1891. Perichaeta hawayana Rosa, Ann. Nat. Hofmus. Wein, 6 396.

1972. Amynthas hawayanus: Sims \& Easton, Biol. J. Linn. Soc., 4(3): 235

1982. Amynthas gracilis: Easton, Aust. J. Zool., 30: 711-735.

Materials examined: 6 ex. Regn. No. IV/ANN/NERC-08. India, Meghalaya, West Khasi Hills District, Domkseh, N 2531'58.4"; E 91'27'42.8”; Alt. 1855m, 25.vi.2010, coll. I.J.Kharkongor and party; 3 ex. Regn. No. IV/ANN/ NERC-16. India, Meghalaya, West Khasi Hills District,

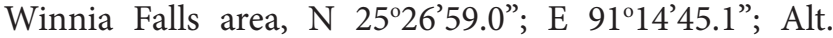
$1318 \mathrm{~m}$, 24.vi.2010, coll. I.J.Kharkongor and party; 3 ex. Regn. No. IV/ANN/NERC-48. India, Meghalaya, West Khasi Hills District, Nongstoiñ-Markasa road, N 2531'51.0"; E 91²2'58.5”; Alt. 1514m, 25.vi.2010, coll. I.J.Kharkongor and party; 3 ex. Regn. No. IV/ANN/ NERC-52. India, Meghalaya, West Khasi Hills District, Nongstoiñ, Siejlieh, N. 2531'47.8”; E 91¹5'13.0”; Alt. 1324m, 26.vi.2010, coll. I.J.Kharkongor and party; 2 ex. Regn. No. IV/ANN/NERC-54. India, Meghalaya, WKH District, Nongstoiñ , N. 25³1'47.8”; E 91¹5'13.0”; Alt. $1324 \mathrm{~m}, 26 . v i .2010$, coll. I.J.Kharkongor and party; 2 ex. Regn. No. IV/ANN/NERC-56. India, Meghalaya, West Khasi Hills District, Nongstoiñ-Siejlieh (stn-2), N 2531'47.8”; E 91¹5'13.0”; Alt. 1324m, 26.vi.2010, coll. I.J.Kharkongor and party.

Diagnosis: Length 56-156 mm; segments 70-101. Epilobic, tongue wide and open. Perichaetine. First dorsal pore in $10 / 11$ or $11 / 12$. Spermathecal pores three pairs in $5 / 6$ 7/8. Clitellum 14-16, annular, with no setae or dorsal pores. Female pore single, mid-ventral on 14. Male pores minute, paired on 18, on small circular porophores. Genital markings small discs, paired, post-setal in some of 6-9 and slightly median to spermathecal pore lines.

Septa 8/9-9/10 aborted. Gizzard bell-shaped, in 8-10. Intestines from 15. Intestinal caeca extending forward from 27. Spermathecae a pair each in $6,7,8$. Ovaries paired in 13. Testis sacs paired in 10 and 11 , ventrally joined. Seminal vesicles a pair each in 11 and 12 .

Distribution: INDIA: Meghalaya (JHD, EKHD), Manipur, Rajasthan, Sikkim, Uttar Pradesh, and West Bengal. Elsewhere: Cosmopolitan.

Remarks: Recorded for the first time from WKHD. The species is also classified as an epi-endogeic species of earthworm as it is generally found living and feeding in the mineral soil at or below the root mat, and also on the surface where there is a rich layer of leaf litter.

\section{Amynthas papulosus (Rosa, 1896)}

1896. Perichaeta papulosa Rosa, Ann. Mus. Genova, 36(2): 525.

Material examined: 2 ex. Regn. No. IV/ANN/NERC-55. India, Meghalaya, WKH District, Nongstoiñ-Siejlieh, N 2531'47.8”; E 91'15'13.0”; Alt. 1324m, 26.vi.2010, coll. I.J.Kharkongor and party.

Diagnosis: Length 45-78 mm. Segments 90-119. Prostomium epilobic. Perichaetine. First dorsal pore in 12-13. Spermathecal pores in 5/6/7/8. Clitellum 14-16, annular, setae usually present on ventral side. Female pore on 14, single and mid-ventral. Male pores a pair on 18. Genital papillae in form of small, pre- and post-setal discs in transverse rows in 7-9. Similar discs also present in transverse rows in 17-19.

Septa 8/9/10 lacking. Gizzard in 8-9. Intestine from 16. Intestinal caeca in 27 extending anteriorly to 22 . Spermathecae paired in 6-8. Ovaries paired in 13. Testis sacs paired in 10 and 11 . Seminal vesicles paired in 11 and 12 .

Distribution: INDIA: Meghalaya (WKHD). Elsewhere: Japan, China, Taiwan, SE Asia.

Remarks: Tentatively conferred to this species as the diagnosis is closest to it, and the species has never been reported from India. Blakemore (2002) has included SE Asia in the distribution range of this species. Since 
Meghalaya is geographically close to the western extremity of SE Asia, there is the possibility of this peregrine species being spread/transported to NE India by anthropogenic means. This species may also be grouped as an epiendogeic species favouring habitats which are moist and rich in minerals and/or in leaf litter.

\section{Amynthas robustus (Perrier, 1872)}

1872. Perichaeta robusta Perrier, Nouv. Arch. Mus. Hist. Nat. Paris, 9: 112.

Materials examined: 1 ex. Regn. No. IV/ANN/NERC-67. India, Meghalaya, WKH District, Mawthadraishan range, Domkseh, N 2531'58.4”; E 91²7’42.8”; Alt. 1855m, 25.vi.2010, coll I.J.Kharkongor and party.

Diagnosis: Length 113-244 mm. Segments 71-138. Prostomium epilobic. Perichaetine. First dorsal pore in $11 / 12$. Spermathecal pores two pairs in $7 / 8 / 9$, ventrolaterally placed. Clitellum 14-16, annular, without setae or dorsal pores. Genital papillae paired and pre-setal in 8 and 9. Female pore single and mid-ventral in 14. Male pores paired in 18 , on a raised papillae with one or more similar papillae around it, and the whole surrounded by circular lines or folds. Additionally, two smaller papillae present mid-ventrally in 18 .

Septa 8/9/10 lacking. Gizzard in 8 and 9. Intestine from 15, caeca in 27. Spermathecae two pairs in 8 and 9. Ovaries paired in 13. Testis sacs paired in 10 and 11 . Seminal vesicle paired in 11 and 12 .

Distribution: INDIA: Meghalaya (WKHD). Elsewhere: China, India, Japan, Korea, Mauritius, Myanmar, Philippines and Taiwan.

Remarks: This peregrine species is, herein, recorded for the first time from Meghalaya. Unlike the previous members of the genus, this species is more robust. It is found on the surface of soils saturated with water and having a layer of decaying vegetable matter. As such, it may be classed as an epigeic species.

Genus 2. Polypheretima Michaelsen, 1934

5. Polypheretima elongata (Perrier, 1872)

1872. Perichaeta elongata Perrier, Nouv. Arch. Mus. Hist. Nat. Paris, 8: 124.
1959. Pheretima elongata: Gates, Bull. Mus. Comp. zool., Harvard, 123: 9.

Material examined: 7 ex. Regn. No. IV/ANN/NERC-03. India, Meghalaya, WKH District, Nongkhnum-Lailad, N 2526’25.8”; E 91¹6’01.4"; Alt. 1377m, 24.vi.2010, coll. I.J.Kharkongor and party; 1 ex. Regn. No. IV/ANN/ NERC-18. India, Meghalaya, WKH District, Nongstoiñ, Mawlongphlang (near JNV), N 2530'32.4'; E 91 '14'23.5”; Alt. $1379 \mathrm{~m}, 26$. vi.2010, coll. I.J.Kharkongor and party.

Diagnosis: Length 75-300 mm. Segments 136-297. Prostomium prolobous or epilobous. Perichaetine. First dorsal pore $12-13$ or 13/14. Spermathecal pores absent. Clitellum 14-16, annular, without dorsal pores but setae maybe present ventrally. Female pore single, mid-ventral in 14. Male pores paired in 18, on raised porophores. Large, raised, pre-setal genital papillae paired in 19-23 or 24.

Septa 8/9/10 absent. Gizzard in 9. Intestine from 15, intestinal caeca absent. Spermathecae absent. Ovaries paired in 13. Two pairs of testis sacs in 10 and 11. Seminal vesicles in 11 and 12.

Distribution: INDIA: Meghalaya (WKHD). Andaman and Nicobar Islands, Andhra Pradesh, Karnataka, Maharashtra, Madhya Pradesh and Tamil Nadu. Elsewhere: Africa, Australia, Bangladesh, Caribbean, Caroline Islands \& Hawaii, India, Madagascar, Myanmar, New guinea, New Caledonia, Pakistan, Papau, Philippines, South and Central America, Sri Lanka and Taiwan.

Remarks: This is another peregrine species recorded for the first time from Meghalaya. It is classified as a mesohumic endogeic species, living and feeding on the upper 0-20 $\mathrm{cm}$ soil strata.

Genus 3. Megascolex Templeton, 1844

6. Megascolex horai Stephenson, 1922

1922. Megascolex horai, Stephenson, Rec. Ind. Mus., 24: 432. 1934. Tonoscolex horai: Gates, ibid., 36: 256.

Material examined: 6 ex. Regn. No. IV/ANN/NERC-04. India, Meghalaya, WKH District, Nongkhnum - Lailad, N 2526'21.8”; E 91²16’01.4”; Alt. 1377m, 24.vi.2010, coll. I.J.Kharkongor and party. 
Diagnosis: Length 50-110 mm. Segments 166-188. Prostomium epilobic, tongue open. Perichaetine, in fairly regular longitudinal lines. Dorsal pores from 10/11. Spermathecal pores two pair in $6 / 7 / 8$, as small transverse slits. Clitellum from 12/13-16/17, distinguishable only from the different colouration. Male pores in 17, postsetal and on small papillae.

Septa 7/8-13/14 slightly strengthened. Gizzard in 7, firm and barrel-shaped. Ovaries in 12. Testis in 9 and 10 . Seminal vesicles in 11 .

Distribution: INDIA: Meghalaya (EKHD, WKHD). Elsewhere: Not recorded.

Remarks: So far, this species has never been recorded from other parts of the country. It is classified as an endogeic - polyhumic species occupying the surface to root zone soil strata. It feeds on soil with a high organic content. Recorded, herein, for the first time from WKHD.

\section{Megascolex sp. 1}

Material examined: 1 ex. Regn. No. IV/ANN/NERC45. India, Meghalaya, WKH District, Nongstoiñ, Mawlongphlang paddy fields, N 2530'28.9"; E91 ${ }^{\circ} 14^{\prime} 19.9^{\prime \prime}$; Alt. 1382m, 26.vi.2010, coll. I.J.Kharkongor and party; 4 ex. Regn. No.IV/ANN/NERC-46. India, Meghalaya, WKH District, Nongstoiñ, Mawlongphlang near JNV, N 2530'28.9”; E 91¹'19.9”; Alt. 1379m, 26.vi.2010, coll. I.J.Kharkongor and party.

Remarks: Placed tentatively in this genus on the basis of morphology, having close resemblance to M. horai Stephenson.

Genus 4. Notoscolex Fletcher, 1887

\section{Notoscolex striatus Stephenson, 1914}

1914. Notoscolex striatus, Stephenson, Rec. Ind. Mus., 8: 380.

Material examined: 1 ex. Regn. No. IV/ANN/NERC-10. India, Meghalaya, WKH District, Nongstoiñ- Siejlieh, N 2531'47.8"; E 91'15'13.0"; Alt. 1324m, 26.vi.2010, coll. I.J.Kharkongor and party; 3 ex. Regn. No. IV/ ANN/NERC-22. India, Meghalaya, WKH District, Mawthar village, near Puiñsneiñ stream, N 2528'05.0”; E
91¹5'39.0"; Alt. 1407m, 24.vi.2010, coll. I.J.Kharkongor and party.

Diagnosis: Length 199-210 mm. segments 290-297, the 4 and 5 biannulate, the rest triannulate. Prostomium prolobic. Lumbricine. First dorsal pore in 9/10. Spermathecal pores minute, in 6/7/8. Clitellum 13-15. Female pores paired in 13. Male pores in the grooves on 17. Genital area from mid-16 to 18 , somewhat rectangular in shape with a depressed centre and longitudinal grooves in the area.

Septa 6/7-10/11 thickened. Gizzard in 6. Intestines from 14. Ovaries in 12. Testis in 9 and 10 . Seminal vesicles in 10,11 and 12 .

Distribution: INDIA: Meghalaya (WKHD), Arunachal Pradesh. Elsewhere: Not known.

Remarks: Stephenson (1923) has mentioned "Rotung and Renging, Abor Country, Eastern Himalayas" as the distribution range of this species. This is also an endogeicpolyhumic species inhabiting the soil surface up to the root mat layer, and feeding on organic matter in the soil.

\section{Notoscolex sp.1}

Material examined: 8 ex. Regn. No. IV/ANN/NERC-31. India, Meghalaya, WKH District, Kriangring village, N2537'59.5”; E 91¹0'00.5”; Alt. 1189m, 23.vi.2010, coll. I.J. Kharkongor and party.

Diagnosis: Length $80-85 \mathrm{~mm}$. segments 200-212, preclitellar segments triannulate except the first 4-5 segments. Prostomium prolobic. First dorsal pore in 9/10 or 10/11. Lumbricine, setae on small pale ridges.

Remarks: Specimens sexually immature.

Genus 5. Nelloscolex Gates, 1939

Lumbricine. Dorsal pores from 8/9/10. Male pores in seminal grooves in 17. Female pores in 13. Digestive system with a big gizzard in 6; no intestinal caeca.seminal vesicles in 10-11.

10. Nelloscolex burkilli (Michaelsen, 1907)

1907. Woodwardia burkilli Michaelsen, Mitt. Naturhist. Mus. Hamburg, 24: 152. 
1939. Nelloscolex burkilli: Gates, Rec. Indian Mus., 41:38.

Material examined: 2 ex. Regn. No. IV/ANN/NERC-15. India, Meghalaya, WKH District, Winnia Falls area, N 2526'59.0”; E 9114'45.1”; Alt. 1318m, 24.vi.2010, coll. I.J.Kharkongor and party.

Diagnosis: length $50 \mathrm{~mm}$. Segments 125. Prostomium prolobic. Lumbricine. First dorsal pore at $9 / 10$. Spermathecal pores two pairs in 7/8 and 8/9. Clitellum annular, from 12-16 or 13-17. Female pore antero-median from setal line in 13 . Testis in two pairs in 9 and 10.

Septa 7/8-15/16 thickened. Gizzard in 6. Intestines from behind 13. Intestinal caeca absent.

Distribution: INDIA: Meghalaya (EKHD, WKHD). Elsewhere: Myanmar.

Remarks: This Burmese species was first reported from India (Meghalaya) by Julka in 1977 (Halder, 1999) with its occurrence in Shillong and Mawphlang (both in EKHD). It is now recorded from WKHD too. This species is found to live in the surface to root zone of the soil. Apparently it feeds on the organic matter in the soil as it is generally found in soils with rich organic content.

Genus 6. Metaphire Sims and Easton, 1972

\section{Metaphire houletti (Perrier, 1872)}

1872. Perichaeta houletti Perrier, Nouv. Archs. Mus. Hist. Nat. Paris, 8: 99.

1900. Pheretima houletti (in part): Michaelsen, Das Tierreich, 10: 273.

1982. Metaphire houletti: Julka, Rec. Zool. Serv. India, 80: 142.

Materials examined: 5 ex. Regn. No. IV/ANN/NERC-38. India, Meghalaya, WKH District, Mawshynrut village, banks of Riangdo river, N2540'41.8”; E91'03'15.8”; Alt. 913m, 22.vi.2010, coll. I.J.Kharkongor and party.

Diagnosis: Length 63-109. Segments 98-105. Epilobic. Perichaetine. First dorsal pore in 7/8-11/12. Spermathecal pores paired, transverse slits in 6/7/8/9. Clitellum annular, 14-16. Female pore single, median, presetal on 14. Combined male and prostatic pores paired, within copulatory pouches on 18 .
Septa 8/9, 9/10 absent. Gizzard between 7/8 and 10/11. Intestine from 15. Intestinal caeca in 28. Seminal vesicles in 11 and 12 .

Distribution: INDIA: Meghalaya (EKHD, JHD, WKHD). Andaman and Nicobar Islands, Himachal Pradesh, Jammu and Kashmir, Karnataka, Kerala and West Bengal. Elsewhere: Australia, Bahamas, Bangladesh, China, Cuba, Fiji, France, Indonesia, Madagascar, Malay Peninsula, Myanmar, Nepal, Pakistan, Philippines, Sri Lanka, Thailand, USA and Vietnam.

Remarks: This tropical, peregrine, lowland species inhabits loamy soils and soils with high moisture content. It is commonly found in well-watered gardens, pastures, under stones/ logs in forests, bamboo groves and in soils near ponds, lakes, streams, etc. It has been classified as an epi-anecic species, inhabiting the surface soil and feeding on the organic matter present in the soil. Recorded, herein, for the first time from WKHD.

\section{Metaphire houletti morph (Gates, 1972)}

1972. Pheretima houletti smaller Hp morph: Gates, Trans. Am Phil. Soc., 62(7): 194.

1982. Metaphire houletti smaller Hp morph: Julka, Rec. zool. Surv. India, 80: 143.

Material examined: 1 ex. Regn. No. IV/ANN/NERC-17. India, Meghalaya, WKH District, Mawlongphlang, near JNV, N 2530'32.4”; E 91¹'23.5”; Alt. 1379m, 26.vi.2010, coll. I.J.Kharkongor and party; 2 ex. Regn. No. IV/ANN/ NERC-21. India, Meghalaya, WKH District, Mawthar village, near Puiñsneiñ stream, N 25²8'05.0"; E 9115'39.0”; Alt. 1407m, 24.vi.2010, coll. I.J.Kharkongor and party; 2 ex. Regn. No. IV/ANN/NERC-28. India, Meghalaya, WKH District, Riangdo village, N2540'41.8”; E9103'15.8”; Alt. 913m; 22.vi.2010, coll. I.J.Kharkongor and party; 1 ex. Regn. No. IV/ANN/NERC-43. India, Meghalaya, WKH District, Mawthadraishan Peak, N25'32'25.6”; E91'27'15.2”; Alt. 1933m; 25.vi.2010, coll. I.J.Kharkongor and party.

Diagnosis: Length 40-130. Segments 90-120. Epilobic. Perichaetine. Genital markings, none externally. Prostates extending from 16-23, ducts variously looped.

Distribution: INDIA: Meghalaya (EKHD, JHD, WKHD). Andaman and Nicobar Islands, Indo-Gangetic Plains to 
Doon Valley, Meghalaya. Elsewhere: Bangladesh, Myanmar, Malay Peninsula, Philippines, Java, FIJI Islands, Formosa, Indonesia, Thailand, Central America, Cuba and USA.

Remarks: Metaphire houletti (Perrier) has seven morphs (Gates, 1972). In Meghalaya, this smaller Hp morph is found. This is an epi-anecic species living on the surface soil and feeding on the organic matter in the soil and also on the leaf litter. Recorded, herein, for the first time from WKHD.

\section{Metaphire birmanica (Rosa, 1888)}

1888. Perichaeta birmanica Rosa, Annal. Mus. Civ. Stor. Nat. Genova, 26: 164.

1900. Pheretima birmanica: Michaelsen, Das Tierreich, 10: 255. 1972. Metaphire birmanica: Sims \& Easton, Biol. J. Linn. Soc., 4(3): 238

Material examined: 1 ex. Regn. No. IV/ANN/NERC-37. India, Meghalaya, WKH District, Mawshynrut village, banks of Riangdo river, N25 40'41.8”; E91'03'15.8”; Alt. $913 \mathrm{~m}, 22 . v i .2010$, coll. I.J.Kharkongor and party.

Diagnosis: Length 112-185 mm. Segments 110-116. Epilobic. Perichaetine. Dorsal pores from 12/13. Spermathecal pores three pairs in 5/6/7/8. Clitellum from 14-16. Female pore single, median, presetal on 14 . Combined male and prostatic pores paired, minute in 18 , on slightly swollen areas which are lighter in colour. Genital markings absent.

Septa 5/6/7 muscular. Gizzard large. Intestine from 15 , intestinal caeca paired in 27 . Seminal vesicles small, in 11 and 12.

Distribution: INDIA: Meghalaya (WKHD). Himachal Pradesh, Uttar Pradesh and West Bengal. Elsewhere: Myanmar.

Remarks: This species occupies habitats identical to those of Metaphire houletti (Perrier), but in wet, clayey soils. It is an epi-anecic species feeding on the decaying leaf litter on the soil surface.

\section{Metaphire posthuma (Vaillant, 1868)}

1868. Perichaeta posthuma Vaillant, Annls. Sci. Nat. (Ser.5), 10: 228
1900. Pheretima posthuma: Michaelsen, Das Tierreich, 10: 295. 1980. Metaphire posthuma: Soota \& Halder, Rec. zool. Surv. India, 76: 200.

Material examined: 2 ex. Regn. No. IV/ANN/NERC27. India, Meghalaya, WKH District, Riangdo village, N2539'52.4"; E9104'20.7”; Alt. 971m, 22.vi.2010, coll. I.J.Kharkongor and party.

Diagnosis: Length 75-140 mm. Segments 91-124. Epilobic. Perichaetine. Dorsal pore from 12/13. Spermathecal pores four pairs, minute, superficial, in furrows 5/6/7/8/9. Clitellum 14-16, annular. Female pore single, on 14 Combined male and prostatic pores paired, minute and invaginated on 18. Genital markings paired circular papillae with centres slightly median to male pore lines on setal arcs of 17 and 19, rarely 20 .

Septa $8 / 9$ or $9 / 10$ absent. Intestine from 15 , intestinal caeca in 27. Ovaries paired in 13. Testis sacs paired, in 10 and 11 , the latter larger. Seminal vesicles paired in 10, 11 and 12 .

Distribution: INDIA: Meghalaya (RBD, WKHD); Andaman and Nicobar Islands, Bihar, Gujarat, New Delhi, Himachal Pradesh, Jammu and Kashmir, Madhya Pradesh, Maharashtra, Orissa, Punjab, Rajasthan, Uttar Pradesh and West Bengal.

Elsewhere: Bangladesh, China, Indonesia, Malaysia, Myanmar, Pakistan, Philippines, Seychelles Archipelago, Taiwan, Thailand, USA and Vietnam.

Remarks: This peregrine species has been recorded from only the warmer and low lying parts of Meghalaya. It inhabits the surface soil layer but may sometimes be found in the root zone layer too. It fees on leaf litter, microbes and organic matter present in its habitat. Therefore, it can be classified as an epi-anecic species.

Genus 7. Perionyx Perrier, 1872

15. Perionyx foveatus Stephenson, 1914

1914. Perionyx foveatus Stephenson, Rec. Ind. Mus., 8: 396.

Material examined: 3 ex. Regn No. IV/ANN/NERC-29. India, Meghalaya, WKH District, Nonglang village, banks 
of Wah Tyrsung, N2540'30.7”; E91¹1'07.6”; alt. 1085m, 23.vi.2010, coll. I.J.Kharkongor and party.

Diagnosis: Length 50-65 mm. Segments 112-140. Epilobic. Perichaetine. Dorsal pore from $4 / 5$ or $5 / 6$. Clitellum annular, from $13-17$ or 13 to half of 18 . Female pore apparently paired and locate just behind $13 / 14$. Male pores on 18, in form of rounded apertures set behind the setal zone. In front of and internal to the male pores is a backwardly convex furrow joining a pair of puckered pits.

Septa regular or uniform. Gizzard in 5. Seminal vesicles two pairs in 11 and 12, the ones in 11 smaller and flattened.

Distribution: INDIA: Meghalaya (WKHD). Arunachal Pradesh, Eastern Himalayas. Elsewhere: Not reported outside of India.

Remarks: The species has been reported from remote places with the least human interference. There has been no record of this species from other type of locations. The location from where the present specimens were collected is also very remote and untouched or unpolluted. Possibly it may be an indicator of environmental pollution and anthropogenic stress on land use. It is a leaf litter feeder found largely on the surface of moist soils covered with vegetations in various stages of decay. Hence, it may be classified as an epigeic or epi-anecic species. Recorded, herein, for the first time from Meghalaya (WKHD).

\section{Perionyx fossus Stephenson, 1920}

1920. Perionyx fossus Stephenson, Mem. Ind. Mus., 7: 214.

Material examined: 1 ex. Regn. No. IV/ANN/NERC49. India, Meghalaya, WKH District, Nongstoin Markasa road, about $4 \mathrm{~km}$ from Makasa, N25'31'51.0"; E91'22'58.5”; Alt. 1514m, 25.vi.2010, coll. I.J.Kharkongor and party.

Diagnosis: Length 85-86 mm. Segments 136. Epilobic. Perichaetine. Dorsal pores from 4/5. Spermathecal pore paired in 7/8 and 8/9. Clitellum annular, from 13-17. Female pore median on 14. Male pores on 18, in cracks at the junction of the floor and sides of the deep, squarish depression marking the male field.

Septa 9/10 slightly thickened. Soft, large gizzard in 6 . Intestine from 17. Seminal vesicles in 11 and 12; those in
11 fused dorsally, and those in 12 fused in their hinder parts, which extend back to 13 .

Distribution: INDIA: Meghalaya (EKHD WKHD).

Remarks: This is a rare, endemic species known from Meghalaya only. It is an epi-anecic species living on surface of moist soils covered with vegetable matter in various stages of decay. It feeds on this decaying matter, and on the microbes associated with such ecological niches. Recorded, herein, for the first time from WKHD.

\section{Perionyx horai Stephenson, 1924}

1924. Perionyx horai Stephenson, Rec. Ind. Mus., 26: 342.

Material examined: 2 ex. Regn. No. IV/ANN/NERC-68. India, Meghalaya, WKH District, Mawthadraishan range, Domkseh village, N2531'58.4”; E91 '27'42.8”; Alt. 1855m, 25.vi.2010, coll. I.J.Kharkongor and party.

Diagnosis: Length $86 \mathrm{~mm}$. Segments 144. Epilobic. Perichaetine. Dorsal pores from $4 / 5$. Spermathecal pores in 7/8 and 8/9. Clitellum annular, 13-17. Male pores minute and presumably in anterior ends of deep grooves in the male field.

Gizzard in 5. Seminal vesicles in 11 and 12, united dorsally in each segment. Prostates in 18 .

\section{Distribution: INDIA: Meghalaya (EKHD, WKHD).}

Remarks: Endemic species known from Meghalaya only. Like the previous species, this species too can be classified as an epi-anecic species living on surface of moist soils covered with vegetable matter in various stages of decay. It feeds on this decaying matter, and on the microbes associated with such ecological niches. Recorded, herein, for the first time from WKHD.

\section{Perionyx excavatus Perrier, 1872}

1872. Perionyx excavatus Perrier, Nouv. Archs. Mus. Hist. Nat. Paris, 8: 126.

1987. Perionyx excavatus: Julka \& Senapati, Rec. zool. Surv. India, Occ. Paper No. 92: 13.

Material examined: 25 ex. Regn. No. IV/ANN/NERC-30. India, Meghalaya, WKH District, banks of Wah Tyrsung, Nonglang village, N2540'30.7”; E91 $11^{\prime} 07.06^{\prime \prime}$; Alt. $1085 \mathrm{~m}, 23 . v i .2010$, coll. I.J.Kharkongor and party. 
Diagnosis: Length 50-80 mm. Segments 115-178. Epilobic. Perichaetine. Dorsal pores from $4 / 5$ or $5 / 6$. Spermathecal pores paired in $7 / 8$ and $8 / 9$. Clitellum annular, in 1317, setae retained. Female pore single, presetal, in 14 . Male pores closely paired in 18 , in clefts in a co mmon depressed but tumid field.

Septa 7/8/9 slightly thickened. Gizzard absent or vestigial in 6 . Intestine from 16,17 , or 18 . Intestinal caeca lacking. Ovaries paired in 13. Testis two pairs in 10 and 11. Seminal vesicles in 9-12.

Distribution: INDIA: Meghalaya (EKHD, JHD, WKHD). Andaman Island, Arunachal Pradesh, Assam, Himachal Pradesh, Karnataka, Tamil Nadu and West Bengal. Elsewhere: Indonesia, Madagascar and its adjacent island, Malaysia, Myanmar, Philippines, Sri Lanka, Taiwan, Thailand, Vietnam and West Indies.

Remarks: This is a temperate, peregrine species generally found in soil rich in organic matters like in manure and compost heaps. It thrives well in domestic wastes, drainage, sewage areas, etc., so it may be used for waste and/or sludge treatments. As this species can be easily cultured, it can be used as a cheaper and alternative poultry and fish feed. Basically, it is an epi-endogeic species feeding on leaf litter and its associated microbes, and on soils with a high organic content. Recorded, herein, for the first time from WKHD.

Genus 8. Kanchuria Julka, 1988

\section{Kanchuria octotheca Julka, 1988}

1988. Kanchuria octotheca Julka, Res. Bull. Sci. Panjab Univ., 39(1-2): 88.

Material examined: 3 ex. Regn. No. IV/ANN/NERC-07. India, Meghalaya, WKH District, Umlieh, Phud-Umlieh, N2532'13.7”; E91'22'18.3”; Alt. 1573 m, 25.vi.2010, coll. I.J.Kharkongor and party; 2 ex. Regn. No. IV/ANN/NERC09. India, Meghalaya, WKH District, Nongstoiñ-Siejlieh, N2531'47.8”; E91'15'13.0"; Alt. 1324 m, 26.vi.2010, coll. I.J.Kharkongor and party; 8 ex. Regn. No. IV/ANN/ NERC-13. India, Meghalaya, WKH District, Pamphyrnai, N2532'19.5”; E91'20'57.0”; Alt. 1556 m; 25.vi.2010, coll. I.J.Kharkongor and party; 1 ex. Regn. No. IV/ANN/ NERC-14. India, Meghalaya, WKH District, Winnia Falls area, N2526'59.0"; E91¹4’45.1”; Alt. 1318 m; 24.vi.2010, coll. I.J.Kharkongor and party; 2 ex. Regn. No. IV/ANN/ NERC-41. India, Meghalaya, WKH District, Nongstoiñ, Mawlongphlang, N2533'32.4"; E91 '14'23.5”; Alt. 1379 m; 26.vi.2010, coll. I.J.Kharkongor and party; 7 ex. Regn. No. IV/ANN/NERC-57. India, Meghalaya, WKH District, on way to Langja village, N2542'27.9"; E91 ${ }^{\circ} 10^{\prime} 45.0^{\prime \prime}$; Alt 1062 m; 23.vi.2010, coll. I.J.Kharkongor and party; 4 ex. Regn. No. IV/ANN/NERC-65. India, Meghalaya, WKH District, Nongstoiñ, Nondeiñ, Soil Conservation Deptt. IB Compound, N2531'34.7”; E91¹5'38.7”; Alt. 1356 m; 26.vi.2010, coll. I.J.Kharkongor and party.

Diagnosis: Length 140-280 mm. Segments 200-440. Prolobic. Lumbricine. Dorsal pores from 11/12. Clitellum one-third 13 or 14-17. Spermathecal pores 4 pairs, minute, mid-ventrum, at 6/7-9/10. Male field slightly depressed on 18, with a pair of co mma-shaped lateral thickenings. Male pores minute in a depression between the lateral thickenings. Genital markings and seminal grooves absent.

Gizzard single in 5. Intestinal origin in 15. Seminal vesicles in 12. Prostates in 18-19. Octothecal.

\section{Distribution: INDIA: Meghalaya (WGHD, WKHD)}

Remarks: This species is endemic to Meghalaya. It was earlier recorded from WGHD, now it is recorded from WKHD also. It is an endogeic- polyhumic species, occupying the surface to root zone layer of the soil and feeding on the organic matter available in its habitat.

\section{Kanchuria sumerianus Julka, 1988}

1988. Kanchuria sumerianus Julka, Res. Bull. (Sci.) Panjab Univ., 39(1-2): 89.

Material examined: 1 ex. Regn. No. IV/ANN/NERC-60. India, Meghalaya, WKH District, Nongstoiñ - Nongkhnum road, about $4 \mathrm{Km}$ from Nongstoiñ, N25'30'26.1"; E91¹7’03.4”; Alt. 1396 m, 24.vi.2010, coll. I.J.Kharkongor and party.

Diagnosis: Length 77-162 mm. Segments 147-269. Prolobic. Lumbricine. Dorsal pores from 11/12. Spermathecal pores two pairs, large longitudinal slits, on posterior margins of 7 and 8. Clitellum 14-17. Genital markings single, median, transversely oval, on 18/19. Male field depressed on 18. Male pores minute, paired, 
on setal line of 18, at anterior ends of seminal grooves and slightly raised circular porophores. Female pore, minute, paired, antero-median in 14.

Intestines from 15. Seminal vesicles in 12. Prostates in 18-21.

Distribution: INDIA: Meghalaya (RBD, EKHD, WKHD), Tripura.

Remarks: This species was described from Sumer under Ri Bhoi district, by Julka (1988). Halder (1999) records its distribution in EKHD. Herein, recorded from WKHD also. It is found in the surface to root zone layer of the soil, feeding on the soil it lives in and therefore, may be classed as an endogeic-polyhumic species.

\section{Kanchuria turaensis Julka, 1988}

1988. Kanchuria turaensis Julka, Res. Bull. (Sci.) Panjab Univ., 39(1-2): 89 .

Material examined: 4 ex. Regn. No. IV/ANN/NERC-62. India, Meghalaya, WKH District, Umjaroo, N25 35'25.0"; E91 ${ }^{\circ} 10^{\prime} 38.8^{\prime \prime}$; Alt. 1189 m, 23.vi.2010, I.J.Kharkongor and party.

Diagnosis: Length 273-335 mm. Segments 279-485. Prolobic. Lumbricine. Dorsal pores from 11/12. Spermathecal pores three pairs, minute, on anterior margins of 7, 8 and 9.clitellum 13-17 or 14-17. Genital marking paired, oval on 18/19. Male field with slightly depressed, central flattened area, and paired obliquely placed lateral depressions on 18. Male pores at anterior ends of seminal grooves. Seminal grooves paired, with posterior ends divergent, turning inwards before terminating in the central apertures of genital markings. Female pore minute, single and median in 14 .

Intestines from 15. Seminal vesicles in 12. Prostates in $18-19,22$.

Distribution: INDIA: Meghalaya (WGHD, WKHD).

Remarks: This endemic species has been recorded from WGHD. It is herein recorded from WKHD. This endogeic- polyhumic species, occupies the surface to root zone layer of the soil and feeds on the organic matter available in its habitat.
Family II: LUMBRICIDAE

Genus 9. Aporrectodea Orley, 1885

Lumbricine. Epilobic. Clitellum saddle-shaped.

22. Aporrectodea trapezoides (Dugès, 1828)

1828. Lumbricus caliginosa trapezoides Dugès, Annls. Sci. Nat., 15: 289.

Material examined: 2 ex. Regn. No. IV/ANN/NERC-33. India, Meghalaya, WKH District, Mawshynrut village,

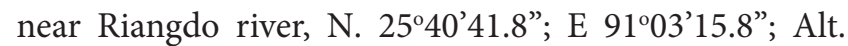
$913 \mathrm{~m}, 22 . v i .2010$, coll. I.J.Kharkongor and party.

Diagnosis: Length 60-220 mm. Segments 130-169. Prostomium epilobic. Tail flat or trapezoid. Setae lumbricine. First dorsal pore 6/7-13/14. Spermathecal pores two pairs in 9/10/11. Clitellum 26,27,28-34,35, saddle-shaped. Female pores as small slits, paired in 14 . Male pore in form of larger slits, paired in 15. Tubercula pubertatis in 30,31-33,34. Genital tumescences in 9-11, and 28,30,32-34. Intestine from 20. Typhlosole from 21. Spermathecae two pairs in 10 and 11 . Ovaries in 13. Testis a pair each in 10 and 11. Small seminal vesicles in 9-12.

Distribution: INDIA: Meghalaya (WKHD). Himachal Pradesh, Jammu and Kashmir. Elsewhere: Cosmopolitan.

Remarks: This is a peregrine species with an almost worldwide distribution. It is recorded for the first time from Meghalaya. Earlier, this parthenogenetic species was accepted as a subspecies of Aporrectodea caliginosa trapezoides (Dugès), but recent phylogenetic studies have established it as a separate identity. Aporrectodea caliginosa trapezoides (Dugès) is an endogeic-polyhumic species of earthworm. Their favoured habitats are moist soils with high organic content.

Family III: OCTOCHAETIDAE

Genus 10. Dichogaster Beddard, 1888

23. Dichogaster bolaui (Michaelsen, 1891)

1891. Benhamia bolaui Michaelsen, Jb. Hamb. Wiss. Anst., 8: 9. 1900. Dichogaster bolaui: Michaelsen, Tierreich, 10: 340. 
Material examined: 1 ex. Regn. No. IV/ANN/NERC-05. India, Meghalaya, WKH District, Nongpyndeng, Nongstoiñ, N2530'38.1"; E91'14'25.5”; Alt. 1382m, 26.vi.2010, coll. I.J.Kharkongor and party; 3 ex. Regn. No. IV/ANN/ NERC-06. India, Meghalaya, WKH District, Umlieh, Phud Umlieh, N2532'13.7"; E91'22'18.3"; Alt. 1573m, 25.vi.2010, coll. I.J.Kharkongor and party; 1 ex. Regn. No. IV/ANN/ NERC-11. India, Meghalaya, WKH District, Pamphyrnai, N2532'19.5”; E91'20'57.0”; Alt. 1556m, 25.vi.2010, coll. I.J.Kharkongor and party; 2 ex. Regn. No. IV/ANN/NERC24. India, Meghalaya, WKH District, Mawthar village, near Puiñsneiñ stream, N2528'05.0”; E91 ${ }^{\circ} 15^{\prime} 39.0^{\prime \prime}$; Alt. $1407 \mathrm{~m}, 24 . v i .2010$, coll. I.J.Kharkongor and party; 2 ex. Regn. No. IV/ANN/NERC-35. India, Meghalaya, WKH District, banks of Riangdo river, Mawshynrut village, N2540’41.8”; E91'03'15.8”; Alt. 913m, 22.vi.2010, coll. I.J.Kharkongor and party; 1 ex. Regn. No. IV/ANN/NERC50. India, Meghalaya, WKH District, on way to Nongstoiñ from Markasa, N2531'51.0”; E91²2'58.5”; Alt. 1514m, 25.vi.2010, coll. I.J.Kharkongor and party.

Diagnosis: Length 20-40. Segments 81-95. Epilobic. Lumbricine; setae closely paired. Dorsal pores from 5/6. Spermathecal pores paired in furrows 7/8/9. Clitellum $13-18$ or $14-18,19$ or 20 , with the intersegmental furrows obliterated. Female pore single and median, in 14. Male pores paired, in slightly concave grooves, on 18 .

Gizzard in 7 and 8 . Ovaries paired in 13.

Distribution: INDIA: Meghalaya (EKHD, WGHD, WKHD), Andaman and Nicobar Islands, Andhra Pradesh, Arunachal Pradesh, Goa, Gujarat, Haryana, Himachal Pradesh, Karnataka, Kerala, Madhya Pradesh, Maharashtra, Orissa, Rajasthan, Sikkim, Tamil Nadu, Uttar Pradesh and West Bengal. Elsewhere: Africa, Australia, Bangladesh, China, Finland, Germany, Hainan, Indonesia, Islands of the Pacific Ocean, Japan, Madagascar and its adjacent islands, Malay Peninsula, Myanmar, North America, Pakistan, Philippines, South America, Sri Lanka, Vietnam and West Indies.

Remarks: An epi-endogeic species with a wide range of climatic and edaphic tolerance. Csuzdi et. al. (2008) has defined it as the first domicole earthworm species for its ability to invade and thrive in urban dwellings. This adaptation makes it a good candidate for use in sewage treatment and waste management processes. Recorded, herein, for the first time from WKHD.

\section{Dichogaster saliens (Beddard, 1893)}

1893. Microdrilus saliens Beddard, Proc. Zool. Soc. London, 1892: 683.

1900. Dichogaster saliens : Eisen, Proc. Calif. Acad. Sci. (ser. 3), 2: 226.

Material examined: 14 ex. Regn. No. IV/ANN/NERC-36. India, Meghalaya, WKH District, banks of Riangdo river, Mawshynrut village, N2540'41.8”; E9103'15.8”; Alt. $913 \mathrm{~m}, 22 . v i .2010$, coll. I.J.Kharkongor and party.

Diagnosis: Length 17-70 mm. Segments 65-122. Prolobic. Lumbricine. Dorsal pores from $4 / 5$ or $5 / 6$, occasionally from $3 / 4$ or $6 / 7$. Spermathecal pores minute, paired, in 7/8 and 8/9. Clitellum 13-19 or 13 to half of 20 , annular, but thinner mid-ventrally. Female pores paired in 14 Male pores at posterior ends of grooves, in 17.

Septa 5/6/7/8 missing. Gizzard two pairs in 7 and 8, displaced posteriorly. Ovaries in 13. Testis paired in 10 and 11. Seminal vesicles lacking, or very small in 11 and 12 , or only in 12 .

Distribution: INDIA: Meghalaya (EKHD, WGHD, WKHD), Arunachal Pradesh, Karnataka, Sikkim and West Bengal. Elsewhere: Angola, Argentina, Australia, Brazil, Christmas Island, Congo, El Salvador, Java, Malay Peninsula, Mexico, Panama, South Africa, Sri Lanka, USA, Uganda and Zaire.

Remarks: This is an epi-endogeic species generally encountered in agro-ecosystems. Populations of this species thrive well in soils enriched with organic substrates. Recorded, herein, for the first time from WKHD.

Genus 11. Eutyphoeus Michaelsen, ?

\section{Eutyphoeus festivus Gates, 1938}

1938. Eutyphoeus festivus Gates, Rec. Ind. Mus., 40: 71.

Material examined: 1 ex. Regn. No. IV/ANN/NERC23. India, Meghalaya, WKH District, Mawthar village, 
near Puiñsneiñ stream, N2528’05.0”; E91¹5’39.0”; Alt. 1407 m, 24.vi.2010, coll. I.J.Kharkongor and party; 4 ex. Regn. No. IV/ANN/NERC-51. India, Meghalaya, WKH District, Mawthadraishan Peak area, N2532'16.9"; E91²7'14.8”; Alt. 1933 m; 25.vi.2010, coll. I.J.Kharkongor and party.

Diagnosis: Length 85-235 mm. Segments 124-271. Lumbricine. Prolobic. Dorsal pore from 10/11. Clitellum 13 or posterior half of 13 to 17 or 18 . Female pore paired presetal, in 14. Male pores in fissures on small, paired porophores in 17. Spermathecal pores as small transverse slits in 7/8. Genital markings unpaired, median on $19 / 20$, occasionally in $18 / 19$ or $20 / 21$ or $22 / 23 / 24$.

Distribution: INDIA: Meghalaya (RBD, EKHD, WKHD).

Remarks: Apparently, this species is endemic to Meghalaya, being recorded from Khasi and Jaiñtia Hills region of the State. This endo-anecic species of soil feeding earthworms are found to inhabit upper $0-20 \mathrm{~cm}$ soil and feed on soils in the $0-10 \mathrm{~cm}$ strata.

\section{Eutyphoeus callosus Gates, 1938}

1938. Eutyphoeus callosus Gates, Rec. Ind. Mus., 40: 67.

Material examined: 2 ex. Regn. No. IV/ANN/NERC58. India, Meghalaya, WKH District, Riangdo village, N25'39'52.4”; E9104'20.7”; Alt. 971 m; 22.vi.2010, coll. I.J.Kharkongor and party.

Diagnosis: Length 247-320 mm. Segments 216-220. Tanylobic. Dorsal pores from 11-12. Clitellum from posterior part of 13-17. Male pores discharge into paired vestibula. Paired, circular, genital markings on 10/1112/13.

Distribution: INDIA: Meghalaya (JH, EKHD, WKHD).

Remarks: The specimens examined is conferred to this species as the diagnosis is closest to E. callosus Gates (as given in Julka, 1988), though some minor differences/ variations are found, like intestine begins from segment 14 instead of 15 . This is also endo-anecic species of soil feeding earthworms found to inhabit upper $0-20 \mathrm{~cm}$ soil and feed on soils in the $0-10 \mathrm{~cm}$ strata.

\section{Order: MONILIGASTRIDA}

Family IV: MONILIGASTRIDAE

Genus 12. Drawida Michaelsen, 1900

Male pores paired at or near inter-segmental furrow 10/11. Female pores paired, at or just posterior to intersegmental furrow 11/12. Spermathecal pores paired, at or close to 7/8. Clitellum in 10-13. Genital markings are rare. Setae lumbricine; almost always very small and closely paired.

\section{Drawida nepalensis Michaelsen, 1907}

1907. Drawida nepalensis Michaelsen, Mitt. Naturh. Mus. Hamb., 24: 146.

1982. Drawida nepalensis: Julka, Rec. zool. Surv. India, 80: 147.

Material examined: 4 ex. Regn. No. IV/ANN/NERC-01. India, Meghalaya, WKH District, Nongkhnum-Lailad, N2526'21.8”; E91 ${ }^{\circ} 16^{\prime} 01.4^{\prime \prime}$; Alt. 1377m, 24.vi.2010, coll. I.J.Kharkongor and party.

Diagnosis: Length 45-132 mm. Segments 115-166. Prolobic. Lumbricine. Dorsal pores absent. Clitellum annular, in 10-13. Male pores paired, on prominent transverse, oval, papillae in furrow 10/11. Spermathecal pores paired in $7 / 8$. Genital markings (in some specimens) present as broad, transversely oval, mid-ventral cushions in segments 7 and 8 .

Septa all present. Two - four gizzards in 12-20. Intestine from 27 or 28. Intestinal caeca absent.

Distribution: INDIA: Meghalaya (EKHD, EGHD, WGHD, JH, WKHD). Andaman and Nicobar Islands, Arunachal Pradesh, Assam, Bihar, Himachal Pradesh, Ja mmu \& Kashmir, Sikkim, Uttar Pradesh and West Bengal. Elsewhere: Bangladesh, Indonesia, Myanmar, Nepal and Pakistan.

Remarks: This endogeic - polyhumic species thrives in soils rich in organic content. But it has been reported that it can live even in soil with little organic matter (Chaudhuri et. al., 2008). It is the most widely used species in vermiculture. Recorded, herein, for the first time from WKHD.

\section{Drawida pellucida var. stewarti Stephenson, 1914}

1914. Drawida pellucida var. stewarti Stephenson, Rec. Ind. Mus., 8: 369. 
Material examined: 1 ex. Regn. No. IV/ANN/NERC26. India, Meghalaya, WKH District, Mawshynrut, N2540'42.7"; E9103'12.0"; Alt. 914 m, 22.vi.2010, coll. I.J.Kharkongor and party.

Diagnosis: Length 37-62 mm. Segments 155-165. Prolobic. Lumbricine; setae moderately large and closely paired. Dorsal pores absent. Male pores on papillae which are surrounded by a circular depression. A transverse dumbbell-shaped ridge on segment 9 just in front of groove $9 / 10$

Four gizzards in $15-18$ or $16-19$, the first one the smallest. Testis sacs pear-shaped, with the narrow end forwards in 9, and the rounded end in 10. Ovisacs small, sausage-shapes in 12 .

Distribution: INDIA: Eastern Himalayas.

Remarks: Reporting for the first time from Meghalaya. This variant of $D$. pellucida is probably endemic to the Eastern Himalayan region. This is classified as an endogeic mesohumic species, having as its niche the upper $0-20 \mathrm{~cm}$ soil layer. It feeds primarily on soils from $0-10 \mathrm{~cm}$ strata.

\section{Drawida pellucida var. typica (Bourne, 1894)}

1894. Moniligaster pellucida Bourne, Quart. J. Mic. Sci., 36: 363. 1900. Drawida pellucida: Michaelsen, Das Tierreich, 10: 118.

1910. Drawida pellucida f. typica: Michaesen, Abh. Ver. Hamburg, 19: 48

Material examined: 1 ex. Regn. No. IV/ANN/NERC-39. India, Meghalaya, WKH District, Mawthadraishan Peak, N2532’25.6”; E91'27’15.2”; Alt. 1933 m; 25.vi.2010, coll. I.J.Kharkongor and party.

Diagnosis: Length 75-190 mm. Segments 130-186. Prolobic. Lumbricine; seate absent in 2. Dorsal pores absent. Contracts its anterior end in a bulbous fashion. Body wall transparent.

Septa 5/6-8/9 thickened. Four or five gizzards, from segments 14-21. Testis sacs round or ovoid in 10. Ovisacs in 12 .

Distribution: INDIA: Meghalaya (WKHD), Arunachal Pradesh and the Nilgiris (Tamil Nadu).

Remarks: Recorded for the first time from Meghalaya. It, apparently, is a high altitude, montane species. Like the previous species, this one too is classified as an endogeic - mesohumic species, having as its niche the upper 0-20 $\mathrm{cm}$ soil layer. It feeds primarily on soils from $0-10 \mathrm{~cm}$ strata.

\section{Drawida rosea Stephenson, 1922}

1922. Drawida rosea Stephenson, Rec. Ind. Mus., 24: 430.

Material examined: 2 ex. Regn. No. IV/ANN/NERC66. India, Meghalaya, WKH District, Nongstoiñ, Nondeiñ, Soil Conservation Department IB compound, N2531'34.7”; E91'15'38.7”; Alt. 1356 m, 26.vi.2010, coll. I.J.Kharkongor and party.

Diagnosis: Length 99-102 mm. Segments 145-149. Prolobic. Lumbricine. Vestiges of dorsal pores visible in the middle region of the body. Male pores on transversely elongated papillae at the hinder border of 10; a pair of smaller, rounder papillae on the anterior border of $11, \mathrm{i}$ mmediately behind the papillae of the male pores. Midventral region between these four papillae depressed and darker in colour. Female pores minute in 11/12 Spermathecal pores conspicuous in 7/8.

Septa 5/6/7/8/9 much thickened. Four gizzards in 1316. Testis sacs in 10 , reaching to septum $10 / 11$. Ovisacs extend back to $13 / 14$

Distribution: INDIA: Meghalaya (EKHD, WKHD).

Remarks: The species is, probably, endemic to Meghalaya. It was earlier reported from EKHD; it is now recorded from WKHD also. This is an endogeic- polyhumic species occupying the surface to root zone soil layer. It feeds on soft, moist soil with high organic content such as those found around forests.

\section{Drawida sp.1}

Material examined: 1 ex. Regn. No. IV/ANN/NERC-53. India, Meghalaya, WKH District, Siejlieh, Nongstoiñ, N25'31'47.8"; E91'15'13.0"; Alt. 1324 m, 26.vi.2010, coll. I.J.Kharkongor and party; 1 ex. Regn. No. IV/ ANN/NERC-61. India, Meghalaya, WKH District, Mawthyhiang, N2540'12.3”; E91²8'00.1”; Alt. 1040 m, 22.vi.2010, coll. I.J.Kharkongor and party.

Diagnosis: Length 30-45 mm . Segments 60-75; anterior segments larger than the posterior segments. Lumbricine. 
Vestiges of dorsal pores visible from 10/11 to few segments posteriorly. Genital markings lacking.

Remarks: The specimens examined are very small and immature, rendering further identification impossible.

\section{Drawida sp. 2}

Material examined: 1 ex. Regn. No. IV/ANN/NERC63. India, Meghalaya, WKH District, Mawthyhiang, N2540'12.3"; E91'28'00.1"; Alt. 1040 m, 22.vi.2010, coll. I.J.Kharkongor and party.

Diagnosis: Prolobic. Lumbricine. Dorsal pores lacking. Spermathecal pores paired, very prominent in $7 / 8$. Segment 10 sunken or with a curved depression in the mid-ventral part. Segment 11 also sunken in the middle but with a very prominent lobe on either side.

Remarks: Interesting specimen, but its post-clitellar portions lost/damaged, making further identification impossible.

\section{Discussion}

During the field surveys ecological observations have been made taking into account both the niche occupied by the earthworms and the general condition of the habitat in its entirety, with the intention of getting an insight in to the ecology of the earthworms. This field observation is augmented with published information or literature gleaned over the years. According to a report by Julka et al. (2009), in India, there are about 590 species of earthworms with different ecological preferences. However, India being partly subtropical and partly temperate, majority of the earthworm species are either epigeic or endogeic and geophagous.

Earthworms are the major secondary decomposers in the soil fauna co mmunity. They feed on the decomposing organic matter at different stages of decomposition or degradation. On the basis of their food niches and ecological niches etc., earthworms have been classified into the following ecological categories (Bouché, 1977; Lee, 1985 and Curry, 1994):

- Epigeic: Detrivorous earthworms that live upon the soil surface or "litter dwellers" and feeding on the decaying leaf litter and the associated microbes.
- Endogeic: Geophagous earthworms that live and feed in the mineral soil at or below the root mat or root zone.

- Anecic: Earthworm that burrow deep in to the soil and feeding on soil and leaf litter on the surface.

- Coprophagic species that live in manure.

- Arboricolous species that live in suspended soils in humid tropical forests.

The geophagous endogeic earthworms are further categorized as polyhumic, mesohumic, and oligohumic, based on the proportion of humus and soil in their feed (Lavelle, 1983). The role of the epigeic earthworms in the soil are as efficient agents of comminution and fragmentation of leaf litter that they transform into stabilized organic matter. Anecic earthworms affects the soil by modifying the physical properties of the soil by their burrowing activity, and by enhancing the decomposition of plant debris by burying and mixing them in the soil (Lavelle, 1988). Endogeic communities, on the other hand, have an impact on the soil aggregation as they feed on soil organic matter that they digest in association with soil micro flora (Barois and Lavelle, 1986; Lavelle, 1984; Lavelle et al., 1989).

Earthworms are the first group of multicellular invertebrates that have successfully colonized terrestrial environments. They are the major soil macrofauna whose species richness, abundance and distribution pattern reflect the edaphic and climatic factors of the geographical zone. Their horizontal and vertical stratification and abundance contribute to pedogenesis and soil profile. The decomposition process of organic matter in terrestrial ecosystems involves a diverse assemblage of soil organisms that interact in a complex way. Among these organisms, earthworms play a key role in determining decomposition rates because of their ability to influence distribution and activity of primary decomposers (bacteria and fungi). Without doubt, earthworms are the most important soil invertebrates in most soils worldwide, in terms of both biomass and activity. Several species are even considered to be ecosystem engineers (Kooch and Jalilvand, 2008) because of their effects on soil properties and their influence on the availability of resources for other organisms, including microorganisms and plants. Earthworms are also known to influence soil structure, soil chemistry and, in particular, process like organic matter decomposition by their positive influence on the 
soil fabric and on the decomposition and mineralization of litter by breaking down organic matter and producing large amounts of faeces, thereby mixing litter with the mineral soil. Therefore, they play an important role in changes from one humus form to another, according to forest succession patterns. For their existence, earthworms depend on adequate moisture, soil texture, $\mathrm{pH}$, electrolyte concentration and food source in the given ecosystem. This clearly indicates the interdependency between the earthworms and the environmental factors for the survival of the former; when such conditions are created, the earthworms further contribute to soil fertility through their activity (Fragoso and Lavelle, 1992; Lee, 1985; Chaudhuri et al., 2008; Edwards and Bohlen, 1996; Bhadauria and Ramakrishnan, 1989, 1991; Kale and Karmegam, 2010).

Earthworms are relatively less sensitive to the influence of different natural external factors but very sensitive to different agro-technical and forestry activities and anthropogenic pollution, making them an appropriate soil quality change bio-indicator (Paoletti, 1999; Julka, 2005). Earthworms have a positive effect on plant growth through their ability to modify the soil (i) chemically, by mineralizing the soil organic matter, (ii) physically, by modifying soil structure (porosity, aggregation, infiltration, run-off, etc.) and (iii) biologically, by activating, dispersing or controlling some plant parasites or symbionts, namely, earthworm activation of symbiotic bacteria. They are, thus, useful when planning forest production improvement, tea plantation restorations and management of other agroecosystems, etc. (Lavelle et al., 1988; Senapati et al., 1994a, 1994b, 1999; Fraser et al., 2003). The practicability of the use of earthworms in determining the influence of different anthropogenic land use forms is attributed to its limited mobility. In such cases, the structure of the earthworm community, as well as their abundance and biomass, were used as endpoints (Römbke et al., 2005).

\section{Conclusion}

A total of 265 exs of terrestrial earthworms were collected during the field survey in WKHD. Collection spots are diverse, including forested areas, river banks, and permanent and natural grasslands, kitchen and flower gardens, roadsides, agricultural fields, etc., and covering ecological niches like under stones, rotten logs, cow- dung manure, etc. Several of the collected specimens are either immature or too slender and fragile rendering taxonomic studies very difficult. The remaining 194 ex of earthworms have been taxonomically identified into 32 species, 12 genera, 4 families and 02 orders. Further, ecologically, these 194 specimens include 6 species (Amynthas corticis, A. gracilis, A. papulosus, A. robustus, Dichogaster bolaui and D. saliens) of epiendogeic earthworms; 8 species (Metaphire houletti, $M$. houletti morph, M. birmanica, M. posthuma, Perionyx foveatus, $P$. fossus, $P$. horai and $P$. excavatus) of epigeic/ epi-anecic earthworms; 11 species (Kanchuria octotheca, K. sumerianus, K. turaensis, Aporrectodea trapezoides, Drawida nepalensis, D. pellucida f. stewarti, D. pellucida f. typica, D. rosea, Drawida sp. 1 and Drawida sp. 2) are endogeic earthworms; 02 species (Eutyphoeus festivus and E. callosus) are endo-anecic worms; 1 species (Polypheretima elongata) is an endo-mesohumic earthworm and 5 species (Megascolex horai, Megascolex sp., Notoscolex striatus, Notoscolex sp. and Nelloscolex burkilli) are endo-polyhumic earthworms. The list also includes 6 species of endemic earthworms namely, Perionyx fossus Stephenson, Perionyx horai Stephenson, Kanchuria octotheca Julka, Kanchuria turaensis Julka, Eutyphoeus festivus Gates and Drawida rosea Stephenson. With the exception of one species, Amynthas corticis (Kinberg) [syn. Amynthas diffringens (Baird)], all the remaining 31 species are recorded for the first time from WKHD, 1 species [Amynthas papulosus (Rosa)] is new record for India and 8 species [ Amynthas robustus (Perrier), Polypheretima elongata (Perrier), Notoscolex striatus Stephenson, Metaphire birmanica (Rosa), Perionyx foveatus Stephenson, Aporrectodea trapezoides (Dugès), Drawida pellucida var. stewarti Stephenson and Drawida pellucida var. typica (Bourne)] are new records for Meghalaya.

According to Lavelle (1983), the detrivorous epigeic earthworms form the major component of earthworm fauna in temperate regions, whereas, the geophagous mesohumic and oligohumic endogeic earthworms are dominant in tropical regions. In high rainfall, subtropical areas like India, the geophagous mesohumic and polyhumic endogeic earthworms are more widely distributed, than the earthworms of the other categories. Parts of the West Khasi Hills District of Meghalaya, particularly the low lying areas bordering the Garo Hills and Assam have a subtropical type of climate with high 
rainfall during the summer months. It is found from the present study that the earthworm communities of the area comprises largely of more widely distributed geophagous polyhumic to mesohumic endogeics, followed by the epi-endogeic and peregrine species of earthworms.

However, with the growth of knowledge about earthworm diversity globally and in Meghalaya, in particular, challenges too have emerged; for instance, morphological ambiguity. In earthworms, some species are morphologically very similar, and some species are intraspecifically very variable. This ambiguity makes it very difficult to distinguish whether two specimens belong to different or the same species. This in turn impedes the description of new species and, thus, our understanding of the earthworm diversity. Nowadays, DNA barcoding is widely used as a supporting tool to resolve this problem. Extensive sampling by workers all over the world has confirmed the usefulness of DNA barcodes in species identification in earthworms (Huang et al., 2007; Chang et al., 2010; Pop et al., 2010). With the aid of DNA barcodes, it is now possible to find out if the observed morphological variations are intraspecific or interspecific, and thus the description of new species can be accelerated, and the possibility that the same species are repeatedly described and named can be reduced. In addition to the discovery of new species, the revision of current taxonomy, the understanding of intraspecific morphological and genetic variations and the investigation of ecology are all important aspects of earthworm biodiversity studies that need to be taken up in the country, in the near future.

\section{Acknowledgements}

The author is grateful to Dr. Ramakhrishna and Dr. K. Venkataraman, Former Directors, Dr. K. Chandra, Director, Zoological Survey of India, Kolkata, Dr. Nibedita Sen, Former Officer-in-Charge, and Ms. J. Lyngdoh, Officer-in-Charge, of ZSI, Shillong, for facilities. The field assistance rendered by Shri K.K. Deb, Ex-Field Collector, Shri Silbaster Swell, Field Assistant, Shri J.R. Lyngdoh, Photographer and Shri G. Japang, Driver, is gratefully acknowledged.

\section{References}

Barois, L. and Lavelle, P. 1986. Changes in respiration rate and some physic-chemical properties of a tropical soil during transit through Pontoscolex corethrurus Glossoscolecidae, Oligochaeta). Soil Biol. \& Biochem., 18: 539-541.

Beddard, F.E. 1883. Note on some earthworms from India. Ann. Mag. nat. Hist. (ser. 5), 12: 213-224.

Bhadauria, T. and Ramakrishnan, P.S. 1989. Earthworm population dynamics and contribution to nutrient cycling during cropping and fallow phases of shifting agriculture (Jhum) in North East India. J. Applied Ecol., 26: 505-520.

Bhadauria, T. and Ramakrishnan, P.S. 1991. Population dynamics of earthworms and their activity in forest ecosystems of North East India. J. Trop. Ecol., 7: 305-318.

Blakemore, R.J. 2012. Cosmopolitan Earthworms - an Eco-Taxonomic Guide to the Peregrine Species of the World. $5^{\text {th }}$ Edition. Verm Ecology, Yokohama, 900 pp.

Bouché, M.B. 1977. Stratégies lombriciennes. In: Soil Organisms as Components of Ecosystems (Eds.U. Lohm and T. Persson,), Ecological Bulletin, Stockholm, vol. 25, pp. 122-132.

Bourne, A.G. 1889. On certain earthworms from the Western Himalays and Dehra Dun. J. Asiat. Soc. Bengal, 58: 110-117.

Chang Chih-Han, Samuel, J., Chen Jiun-Hong, Shen Huei-Ping, Szlavecz Katalin, Chih Wen-Jay and Liao Jyun-Ming. 2010. Regional earthworm DNA barcode database, BOLD system and their applications: a case study from Taiwán. In: Proceedings of the 9th International Symposium on Earthworm Ecology 5th to 10th September 2010, Xalapa, Mexico, abstract no, 26.

Chaudhuri, P.S., Nath, S. and Paliwal, R. 2008. Earthworm population of rubber plantations (Hevea brasiliensis) in Tripura, India. Trop. Ecol., 49(2): 225-234.

Csuzdi, Cs., Pavlicek, T and Nevo, E. 2008. Is Dichogaster bolaui (Michaelsen, 1891) the first domicole earthworm species? Eur. J. Soil Biol., 44: 198-201.

Curry, J.P. 1994. Grassland Invertebrates. Chapman \& Hall, London, 437pp.

Edwards, C.A. and Bohlen, P.J. 1996. Biology and Ecology of Earthworms. Chapman \& Hall, London, 426 pp.

Fedarb, S.M. 1898. On some earthworms from British India. Proc. zool. Soc. London, 1898: 445-450.

Fragoso, C. and Lavelle, P. 1992. Earthworm co mmunities of tropical rain forests. Soil Biol. Biochem., 24: $1397-1408$.

Fraser, P.M., Beare, M.H., Butler, R.C., Harrison-Kirk, T. and Piercy, J.E. 2003. Interactions between earthworms (Aporrectodea caliginosa), plants and crop residues for restoring of a degraded arable soil. Pedobiol., 47 (5-6): 870-876.

Gates, G.E. 1945. Another species of Pheretima from India. Sci. and Cult., Calcutta, 10(9): 403. 
Gates, G.E. 1951. On the earthworms of Sharanpur, Dehra Dun and some Himalayan hill stations. Proc. Nat. Acad. Sci. India (B), 21: 16-22.

Gates, G. E. 1972. Burmese earthworms. An introduction to the systematic and biology of

megadrile oligochaetes with special reference to Southeast Asia. Trans. Am. Phil. Soc., 62(7): 1-326.

Halder, K.R. 1999. Oligochaeta : Earthworm. Fauna of Meghalaya, State Fauna Series, 4(Part 9): 393-439. Zoological Survey of India, Calcutta.

Huang, J., Xu, Q., Sun, Z.J., Tang, G.L. and Su, Y.Z. 2007. Identifying earthworms through DNA barcodes. Pedobiol., 51: $301-309$.

Julka, J.M. 1976. Studies on the earthworm fauna of Orissa (India). 1. Moniligastridae and Ocnerodrilidae. Mitt. Zool. Mus. Berlin, 52: 321-329.

Julka, J.M. 1977. Contribution to the knowledge of the earthworm fauna (Oligochaeta: Annelida) of Meghalaya. Newsl. zool. Surv. India, 3(6): 398-400.

Julka, J.M. 1978. Studies on the earthworm fauna of Orissa (India). 2. Megascolecidae, Octochaetidae and Microchaetidae. Mitt. Zool. Mus. Berlin, 54: 185-197.

Julka, J.M. 1981. Taxonomic studies on the earthworm collected during the Subansiri Expedition in Arunachal Pradesh, India. Rec. zool., Surv. India, Occ. Paper No. 26: 1-37.

Julka, J.M. 1988. The Fauna of India and the Adjacent Countries, Megadrile Oligochaeta, Octochaetidae, xiv+392 pp. (Zoological Survey of India, Calcutta).

Julka, J.M. 1995. Oligochaeta. In: Fauna of Western Himalaya, Himalayan Ecosystem Series, 1 (Uttar Pradesh) 17-22. (Zoological Survey of India, Calcutta).

Julka J.M. 2005. Earthworms as bioindicators in conservation areas. Abstract In: National Seminar on Vermitechnology and Waste Management (Eds. Rajashekar Patil and Rameshchandra Rao), Department of Applied Zoology, Mangalore University, Mangalore. (Sponsored by DBT, New Delhi, India).

Julka, J.M., Paliwal, R. And Kathireswari, P. 2009. Biodiversity of Indian earthworms - an overview. In: Proceedings of Indo-US Workshop on Vermitechnology in Human Welfare (C. A. Edwards, R. Jayaraaj and I. A. Jayraaj, Eds.), pp. 36-56, (Rohini Achagam, Coimbatore, India).

Kale, R.D. and Karmegam, N. 2010. The role of earthworms in Tropics with emphasis on Indian Ecosystems. Applied and Environmental Soil Sc., 2010, Article ID 414356, 16 pages. Doi:10.1155/2010/414356.

Kooch, Y. and Jalilvand, H. 2008. Earthworms as ecosystem engineers and the most important detritivors in forest soils. Pak. J. Boil. Sci., 11(6): 819-825.

Lavelle, P. 1983a. The soil fauna of tropical savannas. II. The Earthworms. In: Tropical Savannas (Ed. F. Bourliere), pp. 485-504. Ecosystems of the World - 13. Elsevier, The Netherlands.

Lavelle, P. 1983b. The Structure of Earthworm Co mmunities. In: Earthworm Ecology (J. Satchell, Ed.), Chapman \& Hall, London. pp. 449-466.

Lavelle, P 1984. The soil system in the humid tropics. Boil. Internat., 9: 2-17.

Lavelle, P. 1988. Earthworm activities and the soil system. Boil. Fert. Soils, 6: 237-251.

Lavelle, P., Barois, I., Martin, A., Zaidi, A. and Shaefer, R. 1989. Management of earthworm populations in agroecosystems: a possible way to maintain soil quality? In: Ecology of Arable Land (Eds. M. Clarholm and L. Bergström), Kluwer, Dortrecht. pp.109-122.

Lavelle, P., Barois, I., Blanchart, E., Brown, G.G., Brussaard, L., Decaëns, T., Fragoso, C., Jiménez, J.J., Ka Kajondo, K., Martinez, M.A., Moreno, A.G., Pashanasi, B., Senapati, B.K. and Villenave, C. 1998. Earthworms as a resource in tropical agroecosystems. Nature \& Resources, 34: 26-41.

Lee, K.E. 1985. Earthworms. Their Ecology and Relationships with Soils and Land Use. pp. ix - 411Academic Press, Sydney.

Michaelsen, W. 1897. Terricolenfauna Ceylons. Jb. hamb. wiss. Anst., 14(2): 159-250.

Michaelsen, W. 1900. Oligochaeta. Das Tierreich, 10: 1-575.

Michaelsen, W. 1907. Neue Oligochaeten von Vorder Indien, Ceylon, Birma und den Andaman-Inseln. Jb. hamb. wiss. Anst., 24: 143-188.

Michaelsen, W. 1909. The Oligochaeta of India, Nepal, Ceylon, Burma and the Andaman Islands. Mem. Indian Mus., 1: $103-253$.

Paoletti, M.G. 1999. The role of earthworms for assessment of sustainability and as bioindicators. Agriculture, Ecosystems and Environment, 74(1999): 137-155.

Pop, A.A., Csuzdi, C. And Pop, V.V. 2006. A new step in using 16S rDNA and COI sequences in the molecular systematic of earthworms (Annelida, Oligochaeta). In: Proceedings of the $8^{\text {th }}$ International Symposium on Earthworm Ecology, $4^{\text {th }}-9^{\text {th }}$ September, 2010, Krakow, Poland. (Abstract no. 10.)

Rosa, D. 1888. Viaggio di Leonardo Fea in Birmanica e regioni vicine, V. Perichetidae. Annali Mus. civ. Stor. nat. Giacomo Doria, 6: 155-167. 
Rosa, D. 1890. Viaggio di Leonardo Fea in Birmanica e regioni vicine, XXVI. Perichetidae. Annali Mus. civ. Stor. nat. Giacomo Doria, 10: 107-122.

Römbke, J., Jänsch, S. and Didden, W. 2005. The use of earthworms in ecological soil classification and assessment concepts. Ecotoxicol. Environ. Saf., 62(2): 249-265.

Senapati, B.K., Panigrahi, P.K. and Lavelle, P. 1994a. Macrofaunal status and restoration strategy in degraded soil under intensive tea cultivation in India. In: Transactions of the $15^{\text {th }}$ World Congress of Soil Science, 4A: 64-75. (ISSS, Acapulco, Mexico).

Senapati, B.K., Panigrahi, P.K., Giri, S., Patnaik, A. and Lavelle, P. 1994b. Restoration of degraded soil in intensive tea plantation (India). In: Conservation of Soil Fertility in low input agricultural systems of the humid tropics by manipulating earthworm co mmunities, CCE Macrofauna Project II(STD3) Report No. 3, ed. P. Lavelle: 39-51. (LEST/IRD, Paris).

Senapati, B.K., Lavelle, P., Giri, S., Pashanasi, B., Alegre, J., Decaëns, T., Jiménez, J.J., Albrecht, A., Blanchart, E., Mahieux, M., Rousseaux, L., Thomas, R., Panigrahi, P.K. and Venkatachalan, M. 1999. In-soil technologies for tropical ecosystems. In: Earthworm Management in Tropical Agroecosystems (Eds. P. Lavelle, L. Brussaard and P. F. Hendrix): 199-237. (CAB International, Wallingford).

Stephenson, J. 1914. On a collection of Oligochaeta, mainly from Northern India. Rec. Indian Mus., 10: 321-365.

Stephenson, J. 1916. On a collection of Oligochaeta belonging to the Indian Museum. Rec. Indian Mus., 12: $299-354$.

Stephenson, J. 1922. Some earthworms from Kashmir, Bombay and other parts of India. Rec. Indian Mus., 24: 427-443.

Stephenson, J. 1923. Oligochaeta. The Fauna of British India, including Ceylon and Burma, xxiv+518 pp. (Taylor and Francis Ltd., London).

Templeton, R. 1844. Description of Megascolex caeruleus. Proc. zool. Soc. London, 12(1844): 89-91. 